Spring 2006

\title{
Arsinoe II as Epic Queen: Encomiastic Allusion in Theocritus, Idyll $15^{*}$
}

Andrew Foster

Fordham University, foster@fordham.edu

Follow this and additional works at: https://fordham.bepress.com/classics_facultypubs

Part of the Classics Commons

\section{Recommended Citation}

Foster, Andrew, "Arsinoe II as Epic Queen: Encomiastic Allusion in Theocritus, Idyll 15*" (2006). Faculty Publications. 1. https://fordham.bepress.com/classics_facultypubs/1

This Article is brought to you for free and open access by the Classical Languages and Civilizations at DigitalResearch@Fordham. It has been accepted for inclusion in Faculty Publications by an authorized administrator of DigitalResearch@Fordham. For more information, please contact considine@fordham.edu. 


\section{Arsinoe II as Epic Queen: Encomiastic Allusion in Theocritus, Idyll 15*}

\section{J. ANDREW FOSTER}

Fordham University

SUMMARY: This paper will illustrate how Idyll 15's intertextual affiliation with the Odyssey and Greek historiography embellishes the poem's explicit encomium of Arsinoe II. By alluding to Arete, Circe, and Helen and augmenting these allusions with reports of Egypt and Egyptian conquerers given by Herodotus and Hecataeus, Theocritus subtly depicts Arsinoe II as a semi-divine Greek and Egyptian queen whose wealth, status, and beneficence exceeds even that of the Homeric women to whom she is compared.

THEOCRITUS'S FIFTEENTH IDYLL IS A PECULIAR COMBINATION of a literary mime and a cult hymn. Opening with the Syracusan matron, Gorgo, knocking on the door of her compatriot, Praxinoa, the poem rapidly expands beyond a single setting in Praxinoa's home on the outskirts of Alexandria to track mimetically the progress of the two women to the court of Ptolemy Philadelphus where they will witness queen Arsinoe's Adonia. After a bit of misadventure on the road to the palace, they enter the queen's precincts, view the luxuriant tableau of cult figures, and listen to a professional singer deliver a hymn upon whose conclusion Gorgo and Praxinoa depart for their home and their routine.

Beyond the Idyll's generic interest in low mimesis that comically catalogs a domestic life replete with dim-witted husbands, indolent slaves, and the everyday annoyances from which royals are exempt, the poem also recreates through the eyes and ears of the visiting matrons the song and scenery of

* The author would like to thank audiences at the University of Chicago, Pennsylvania State University and Fordham University as well as C.A. Faraone, E.A. Asmis, D.L. Wray, and R.L. Hunter, each of whom offered many useful comments on much earlier versions of this article. I would especially like to thank TAPA's anonymous readers and C. Damon who devoted a great deal of time and effort to provide me a very detailed road map to revision. All errors in style and substance remain my own. 
the queen's festival. A partial image of the festal skene with a central tableau depicting Adonis and Aphrodite in their annual first and final embrace emerges from Gorgo's and Praxinoa's banter. Their dialogue gives way to the voice of an anonymous Argive singer who offers a more detailed ecphrasis of the cult scene. Her hymn to Aphrodite (and Adonis) embedded within the mime describes the accoutrements that the queen lavishes upon the goddess and her consort. The singer catalogs the luxurious tapestries, precious metals, sumptuous foods, unguents, and aromatics surrounding the statuary seated upon a gilt couch decorated with ebony and ivory. ${ }^{1}$ She then bids farewell to the divine couple by adumbrating the following day's closing rites and by listing certain epic and mythic figures who do not share in Adonis' semidivine privileges.

Although its mimetic component has won much praise, the Idyll's hybrid structure and especially the singer's hymn found little favor among a number of earlier critics. They consider the hymnist's song a clumsy piece of court encomium that obscures the mime's biting wit. ${ }^{2}$ Yet, more recent commentators have more fully demonstrated the poem's formal subtleties and thematic complexity. ${ }^{3}$ In this paper, I will illustrate one facet of the poem's subtle sophistication that has been largely overlooked: the Idyll's intertextual affiliation with the Odyssey and Greek historiography that invites the reader to create an eidôlon of Arsinoe that emphasizes her identity as a semi-divine Greek and Egyptian queen whose wealth, status, and beneficence exceeds the elevated company of the Greek heroines and divinities to whom she is compared.

\section{IDYLL 15 AS ROYAL ENCOMIUM}

Even the most casual reading of Idyll 15 would easily lead to the scholiast's conclusion that Theocritus had found favor with the queen while living in Alexandria. ${ }^{4}$ Gorgo's and Praxinoa's colorful dialogue is embroidered with overt praise of the royals. ${ }^{5}$ In addition to their explicit praise, the matrons effuse over the lush festal scene that Arsinoe has provide for Adonis and

${ }^{1}$ Following Gow 1938: 194; Gow 1952: 2.298-9, I assume that there is one couch.

${ }^{2}$ E.g. Dover 209-10; Gow 1938: 202; Legrand 1898: 138.

${ }^{3}$ E.g. Burton 137-46; Hunter 1996: 123-38.

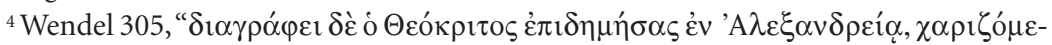

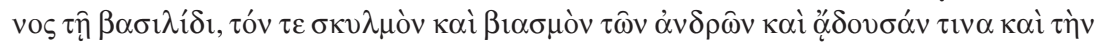

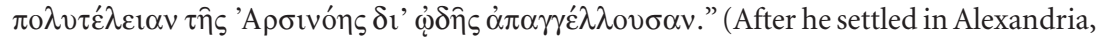
Theocritus, finding favor with the queen, describes the annoyance and abuse of men and describes a certain woman singing about the wealth of Arsinoe in an ode [all English translations from other languages are my own unless otherwise indicated]).

${ }^{5}$ E.g. 15.22-4, 46-50. 
Aphrodite (15.78-86). They thereby implicitly extol the queen's religious devotion and public generosity.

The hymnist amplifies the matrons' implicit and explicit praise. Her hymn broadcasts the queen's liberality towards her subjects, filial devotion to her divinized parents, and reverence for the gods. Likening Arsinoe to Helen

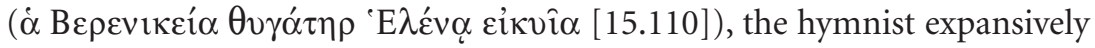
reminds Aphrodite of the extravagant decor the queen has furnished for the goddess' consort, Adonis (15.111-27). Since the hymnist recalls that Aphrodite divinized the queen's mother, Berenice (15.106-8), Arsinoe's festival also serves to advertise the divine status of Ptolemaic ancestors as well as the queen's service to the goddess who may well engineer Arsinoe's own future apotheosis. By replacing the central narrative of the goddess's aristeia with an ecphrasis of the cult scene and praise of the queen for providing it, the hymn becomes more an encomium of Arsinoe than a hymn to Aphrodite. Whether her song is aesthetically wanting or not, there is no doubt that it is the centerpiece of a royal encomium that aims to enumerate and extol the queen's munificence. $^{6}$

The poet's overt and oblique praise of Philadelphus and his senior sisterwife enmeshed within the framework of an urban mime containing a cult hymn is hardly unusual for Theocritus. Dramatic personae in the bucolic, Idyll $7,{ }^{7}$ and the mime, Idyll $14,{ }^{8}$ digress to offer effusive, if not gratuitous, praise of Ptolemy Philadelphus. Hymns and "epyllia" devoted to Greek figures such as the Dioscuri, Dionysius, Heracles, and Helen can be read as poems designed to cast a pleasing light upon the Ptolemies while the poet experiments with the form and content of hexameter poetry. ${ }^{9}$

Given the Ptolemies' peculiar position as foreign conquerors assuming the identity of native kings to legitimate their hold over Egypt, it is not surprising that Theocritus's encomiastic strains often strike an Egyptian undertone. As Stephens has recently shown, Idylls 17 and 24 assimilate Ptolemy Philadelphus and his heroic ancestor, Heracles, to the Egyptian Pharaoh and world

${ }^{6}$ As noted by many, especially: Griffiths 1981: 256-9; Legrand 1927: 1.118-9; Reed 320-1; Whitehorne 73-4.

${ }^{7}$ Veiled praise of Ptolemy is found at 7.91-3. See especially Gow 19522.155 n. 93, Hunter 1999: 146, 179 n. 93; Bowie 68. Brown, 97 argues that 7.91-93 is not praise directed to Ptolemy Philadelphus, but a reference to Mt. Zini in Crete.

${ }^{8}$ Ptolemy is openly praised at 14.58-64. See Gow 1952: 2.259-60 nn. 60-3; Hunter 1996: 115.

${ }^{9}$ Griffiths: 1979: 86-106, offers an excellent general overview of the encomiastic component of Theocritus's mythological poetry. Cf. Fantuzzi and Hunter 275-9; Koenen 79-86; Pantelia; Stephens 122-46 for specific discussions. 
conqueror, Sesoösis (Sesostris). ${ }^{10}$ Idyll 15 itself also embraces images and narratives of Egyptian cult and royal ideology to emphasize the legitimacy of Ptolemaic occupation of the Egyptian throne. ${ }^{11}$ In keeping with this Egyptian vision encoded within Arsinoe's festal décor, several of the epic allusions that Theocritus threads within Gorgo's and Praxinoa's dialogue and the singer's hymn emphasize Arsinoe's Egyptian identity while depicting her in terms of semi-divine female hosts who display their beneficent poluteleian to the guests they entertain. Theocritus, much as he does in Idylls 17 and 24, embellishes the Egyptian aspect of these epic allusions with traditions of Egypt and Egyptian conquerors recorded by Herodotus and Hecataeus. The poet thereby offers an image of Arsinoe as not simply a reflection of her epic forbears but also as the mistress of a house that is Egypt — an Egypt constituted by her conquering consort-Pharaoh, Ptolemy Philadelphus.

\section{ARSINOE AS EPIC QUEEN}

Despite its mimetic facade and relatively weak overt epic register, ${ }^{12}$ the "plot" and overall content of Idyll 15 are reminiscent of hospitality scenes in the Odyssey. ${ }^{13}$ Recalling Telemachus traveling to Nestor's palace, Telemachus and Peisistratus to Helen and Menelaus's home, Odysseus and his men to Circe's cave, and, most famously, Odysseus to Alcinous and Arete's palace, Idyll 15 presents Gorgo and Praxinoa traveling to a palace where they are awed by the decor and entertained by their royal patrons until domestic "reality" beckons them to depart the fantastic realm of the palace precincts. In these respects, their visit to Alexandria broadly parallels Odysseus's stay on Phaeacia. ${ }^{14} \mathrm{Be}-$ yond the general structural correspondence, the poet vaguely alludes to this specific hospitality scene through the Argive singer's voice (15.115-7; trans. Gow 1952):

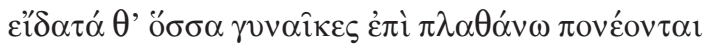

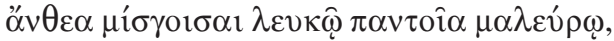

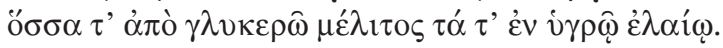

${ }^{10}$ Stephens 142-6; 159-63.

${ }^{11}$ See especially Reed.

${ }^{12}$ Hunter 1996: 120, but see Griffiths 1979, 121-3 for an analysis of how effectively Theocritus exploits the language of Homer within the Idyll.

${ }^{13} \mathrm{On}$ the form and content of Homeric hospitality scenes, see Arend; Reece. For a study of hospitality scenes in which women function as the host, see Pedrick. For an extended analysis of Idyll 15 as a hospitality scene, see Foster 102-21.

${ }^{14}$ Foster 102-7. 
And all the cates that women fashion on the kneading tray, mingling every hue with fine white wheat-flower, are there, and those they make of sweet honey and with smooth oil.

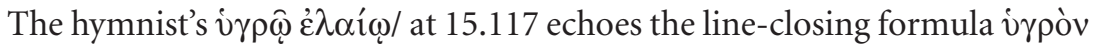
¿่ $\lambda \alpha$ íov found four times in the Iliad and Odyssey (Il.23.281; Od.6.79; 6.215; 7.107). Of the four occurrences, two are explicitly connected to Arete $(\mathrm{Od}$. $6.79,215)$ while a third occurs while Odysseus tarries in her palace $(O d$. 7.107). ${ }^{15}$ Changing the case from accusative to dative and altering the context from anointing bathers or treating cloth to moistening dough are a classic example of a Hellenistic poet engaged in a bit of Homeric variatio. These innovations do not obscure the source of the phrase, since its Homeric context resembles the scene created by the hymnist's voice: a generous queen residing in a splendid palace scrupulously entertaining guests.

The Idyll's broad correspondences with and specific allusion to Odysseus's encounter with Arete is hardly surprising, given Arete's paradigmatic status as sage Greek queen and the poem's encomiastic pretensions. ${ }^{16}$ The wise counselor, compassionate host, and ultimately deferential spouse is an excellent source (at least for a Greek male) from which to fashion an ideal portrait of Arsinoe. Yet, Theocritus never fully develops the glancing allusion to Arete into a mirror reflecting Arsinoe's virtues. Instead, the poet creates a complex amalgamation of images by alluding to Circe and Helen as well.

When Gorgo and Praxinoa force their way into the palace they are stunned by the beauty of the textiles adorning Aphrodite and Adonis's apartment. Gorgo exclaims (15.78-9):

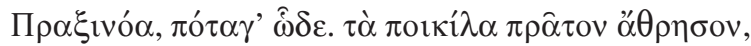

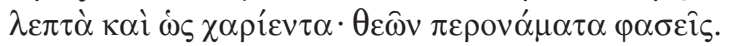

Praxinoa, come here, look first at the weavings, how fine and how pleasing they are, you would say they are clothes fit for gods.

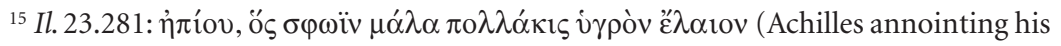

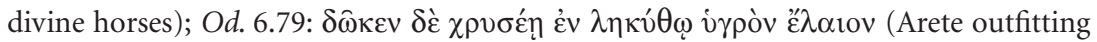

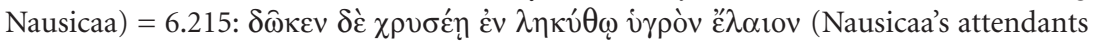

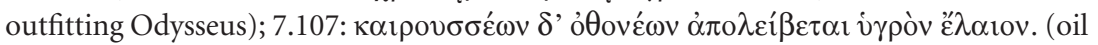
dripping from weaving threads). For an explanation of the use of oil in the preparation of thread for weaving, see Heubeck, West, and Hainsworth 1.328-9 n.107.

${ }^{16}$ For Arete as paradigm, see Pomeroy 18. For Arsinoe as Arete, see Hunter 2003: 94, 128-9 n. 38-9, 166-7 n. 90-1. Mori explores the Arete episode in the Argonautica of Apollonius Rhodes (A. R. 4.982-1222) as a poetic depiction of Arsinoe's role within the Ptolemaic court. 
In his commentary, Gow observes that Gorgo's description of the tapestries as

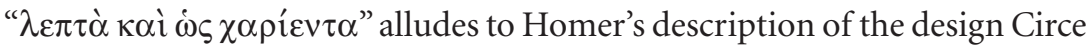
is weaving as Odysseus' men venture into her cave (Od. 10.221-3):17

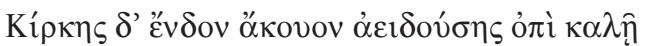

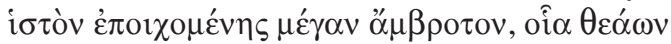

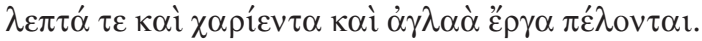

They heard Circe inside singing with a beautiful voice as she went up and down upon her divine loom, glorious works, as are things of gods, delicate and fine.

Although the phrase occurs at three other places in Homer, Gow rightfully privileges Odyssey 10.223 as Circe's cave is the only hospitality scene in which the formula is used and therefore corresponds most closely with the setting and sequence of action in Idyll 15. ${ }^{18}$

The poet would also seem to have established proleptically the specific location of the allusion as just before Gorgo alludes to Circe, Praxinoa had

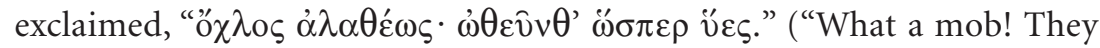
push and shove just like pigs" [15.72-3]) as if she were anticipating Gorgo's allusion to Odyssey 10 by assimilating the Alexandrian crowd to Odysseus's

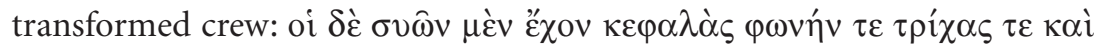
$\delta \varepsilon_{\mu \alpha \varsigma}$ ("And they had the head, voice, hair, and body of pigs" Od. 10.239-40). Gorgo and Praxinoa might not much resemble Odysseus beyond sharing roles within a hospitality scene, ${ }^{19}$ but casting Arsinoe in Circe's part cleverly underscores Arsinoe's hybrid identity as a Macedonian/Greek queen and Egyptian royal consort who treads the boundary between human and divine.

Perhaps Theocritus might shy away from associating Arsinoe with the Circe we initially meet in the Odyssey. A treacherous witch who transforms Odysseus' witless crew into beasts, Circe only fails to do the same to the hero at sword point. This suggestion may resonate too deeply with Arsinoe's way-

${ }^{17}$ Gow 2.287 n. 79.

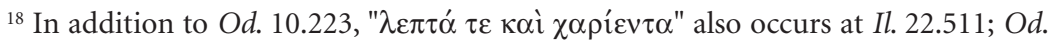
5.231 and $\mathrm{Od}$. 10.544. The contexts are all similar in that the formula describes clothing

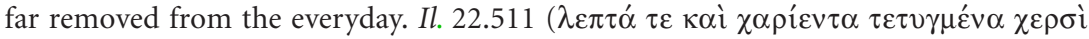

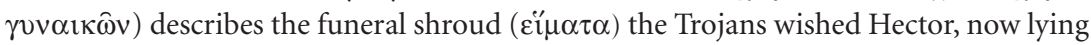

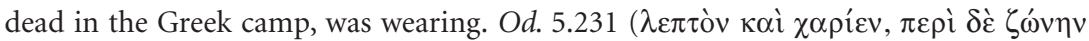
$\beta \alpha \dot{\alpha} \lambda \varepsilon \tau$ ' $i \xi v \hat{\imath}$ ) describes the cloak ( $\varphi \hat{\alpha} \rho \varsigma$ ) with which Calypso outfits Odysseus. Od. 10.544 repeats the formula used at 5.231 to describe Circe's outfit. Cf. Burton 173-5.

${ }^{19}$ Cf. Hunter, 2003: 128-9 n. 38-9 who cautiously suggests that we might consider Gorgo and Praxinoa as akin to Odysseus admiring the décor as he enters the palace of Alcinous. 
ward past when she too was thought to be adept at poisons and not afraid to exploit the naiveté of the unsuspecting to her own advantage. ${ }^{20}$ Yet even in the Odyssey, Circe ultimately proves a great benefactor of Odysseus and his crew. Returning his men to their previous form, she outfits the hero and offers sage advice concerning his impending visit to the underworld. ${ }^{21} \mathrm{~A}$ dubious past erased by subsequent beneficence may make for a less than compelling point of contact between Arsinoe and Circe, yet if we look beyond the Odyssey to Herodotus's Histories and Apollonius's Argonautica, the Idyll's evocation of Circe becomes much more apropos of Arsinoe's status as a benevolent Egyptian queen of Greek extraction.

Circe, the daughter of Helios, is a Colchian. According to Herodotus, Colchians are ultimately descended from Egyptians as their shared language illustrates. $^{22}$ Circe is thus by extension also Egyptian. Apollonius of Rhodes highlights Circe's and Medea's dual cultural identities as foreigners assimilated to Greek epic, by pointedly representing Circe and Medea as speaking in their native tongues after Circe has taken pity upon the girl and purified her of the murder of her brother, Apsyrtus (A.R. 4.725; A.R. 4.730-2):

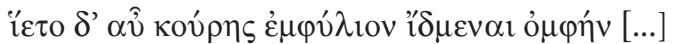

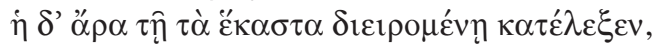

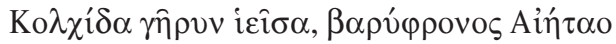

коú $\rho \mu \varepsilon \imath \lambda \imath \chi i \omega \varsigma$.

Circe was eager to hear the kindred voice of the girl. [...]

Speaking in Colchian, the daughter of cruel-minded Aietes

thoroughly and graciously answered everything Circe

closely questioned.

${ }^{20}$ It was widely believed that Arsinoe, when she was wed to Lysimachus, then regent of Macedon, poisoned her stepson, Agathocles, in order to clear the way for her children's (by Lysimachus) ascent to the Macedonian throne. As Justin reports (Epit. 17.1.4): "nam breui post tempore Agathoclem, filium suum, quem in successionem regni ordinauerat, per quem multa bella prospere gesserat, non solum ultra patrium, uerum etiam ultra humanum morem perosus ministra Arsinoe nouerca ueneno interfecit." (... a little later Lysimachus, having grown to hate his own son, Agaothcles, with an intensity beyond what a father might feel and even beyond what a human should, killed him with the help of his stepmother Arsinoe's poison even though Lysimachus had designated Agathocles as his successor and through him had won many wars). Cf. Paus., 1.10:3-4. For varying assessments of Arsinoe II's career and character see Bevan 57-64, 71; Burstein; Green 145-6 and notes; Hazzard 81-100; Hölbl 35-6; Macurdy 111-30; Pomeroy 14-20, 34-8.

${ }^{21}$ According to Hesiod Circe also bears Odysseus three sons (Hes. Th. 1111-6). Apollodorus relates that Circe transported the only son with whom he is familiar, Telegonus, along with Penelope to the Islands of the Blest (Apollod. Epit.7.16, 36-7).

${ }^{22}$ Hdt. 2.105 
The Circe of Alexandrian poetry is both a Greek goddess of epic and a foreigner who speaks an alien tongue. When Apollonius's episode is filtered through the lens of Herodotus, Circe's Egyptian heritage is plain to see. Colchians are Egyptians. Circe is Colchian, ergo Circe is Egyptian. Whether the allusion to Circe in Idyll 15 should be read through Argonautica 4 with Herodotus in mind, or we should imagine that Circe's Egyptian pedigree was a general Alexandrian trope current among the literati so taken with delivering royal encomia in the language of epic, Circe does provide a unique point of contact with Arsinoe: both of these divine benefactors straddle the boundary between mortals and gods and are simultaneously Egyptian and Greek. ${ }^{23}$ The hymnist continues to affiliate Arsinoe with Greek demi-goddesses connected to Egypt when she compares Arsinoe to Helen. And as the hymnist develops that comparison she repeatedly alludes to Odyssey 4 and its recollection of Helen's extended stay in Egypt.

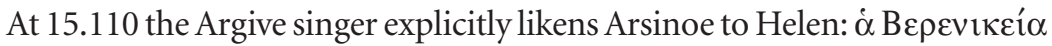

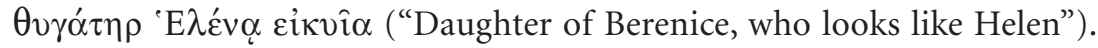
Although the initial point of contact is their shared physical beauty, associating Arsinoe with Helen within the Egyptian context of Arsinoe's civic celebration immediately calls to mind the extensive Greek literary traditions of Helen in Egypt.

The fragment of Stesichorus's famous Palinode (P. Phaedrus 243) may never specify where Helen tarried as the Greeks and Trojans battled about Troy over her "phantom," ("हi' $\delta \omega \lambda$ ov" E. Hel., 34), ${ }^{24}$ but Herodotus (2.112-9) reports that Egyptians believe the heroine had been compelled to stay in Egypt by their king, Proteus, who would not permit Paris to enjoy the fruits of his theft. Proteus reunites Helen and Menelaus, who depart for Greece laden with gifts, but her presence in Egypt lingers in the form of the cult of "Aphrodite the Stranger," whom Herodotus suggests is merely Helen in disguise (Hdt. 2.112).

In his Helen, Euripides reiterates Herodotus's account of Helen in Egypt and also speaks of her eidôlon, an image that might hearken back to Stesi-

${ }^{23}$ It should also be noted that as evidence for the Colchians Egyptian heritage Herodotus (2.105) also cites the Colchian's and the Egyptian's shared and distinctive method of weaving. Given how prominently weaving figures into the Idyll and that the allusion to Circe is precisely when she is found weaving, it becomes very difficult to imagine that Theocritus does not have Herodotus 2.105 in mind as he alludes to Circe at her loom.

${ }^{24}$ Although the commentary on lyric poetry preserved in Stesichorus fr. 193 PMG (=POxy. 2506, fr. 26, col. I) states that the poet knows both of Helen's eidôlon and of her tarrying in Egypt, I share Austin's skepticism over the reliability of this testimony. Austin 96-99, esp. nn. 13-14. 
chorus since the marginal comments preserved in POxy 2506 (PMG 193) claim that the Sicilian poet also wrote of Helen's phantom. ${ }^{25}$ Euripides' Helen not only shares an affiliation with Egypt, but like Arsinoe, she is associated with her brothers, the Dioscuri, the guardians of seafarers. In the Orestes, the gods snatch Helen from the murderous Orestes and locate her in the aithêr where she, along with the Dioscuri, will protect sailors. Arsinoe is similarly translated to heaven in Callimachus' "Ektheosis Arsinoes" (fr. Pfeiffer 228). ${ }^{26}$ Arsinoe also became a protector of sailors as the Ptolemaic naval commander, Callicrates, dedicated a temple to Arsinoe qua Aphrodite Zephyritis at Zephyrion. ${ }^{27}$ Seen in light of extra-Homeric traditions of Helen in Egypt, the resonance with Callimachus' subsequent association of Arsinoe with the Dioscuri and the realia of contemporary cult worship, Donzelli rightly concludes that Theocritus's comparison of Arsinoe to Helen is high praise: "per il momento Teocrito paragonerà Arsinoe alla casta Elena, fedele sposa di Menelao, sorella dei Dioscuri, regina del mare." ${ }^{28}$ Beyond this broad template of shared associations with Egypt, divinity, the Dioscuri, and the sea, the poet clarifies the image of Arsinoe as a munificent Helen with Egyptian connections by a number of allusions to Odyssey 4 where Telemachus meets Helen returned to Sparta.

As she enumerates the "many good things" with which Arsinoe outfits

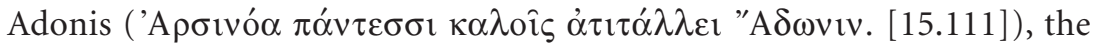
Argive singer echoes the list of luxuries found in Menelaus's palace in Sparta.

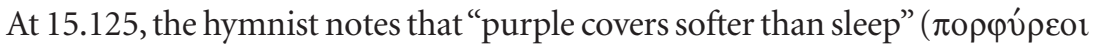

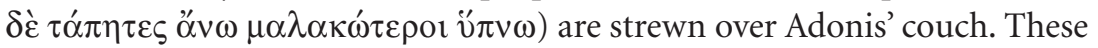
garments are reminiscent of the cover of soft wool that her servant, Alkippe, brings Helen at Odyssey 4.124, “А А ("Alkippe brought a cover of soft wool"). Although this cover may not be part of the gifts Helen and Menelaus received from their Egyptian hosts, Helen's silver basket is a gift of Alkandre, "the wife of Polybus king of Egyptian Thebes" (Od. 4.124-7):

${ }^{25}$ Cf. Hdt 2.113-120. In addition, in the Helen, Castor, as he bids Orestes to quit Argos, explains that Helen tarried in Egypt while Zeus fashioned her eidôlon to stir up strife among mortals (E. El. 1280-3). For Stesichorus and Helen's eidôlon, see note 24.

${ }^{26}$ Dieg. X 10 (Pfeiffer 1.218) declares that Arsinoe is "snatched up" ( $\dot{\alpha} v \eta \rho \pi \alpha ́ \sigma \theta \alpha \mathrm{l}$ ) by the Dioscuri. For a recent discussion of the "Ektheosis Arsinoes" see Hunter 2003: 50-3. Cf. Donzelli 310, 314.

${ }^{27}$ Fraser 1.197, 239-40, 568-9. Cf. Gow-Page, HE 3110-19 for Posidippus' dedicatory epigram of the shrine.

${ }^{28}$ Donzelli 316. 


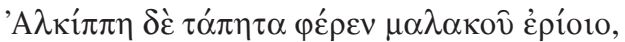

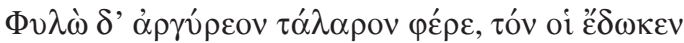

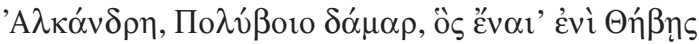

Airvoríns.

And Phylo brought a silver basket, which Alkandre, Polybus' wife, who lived in Egyptian Thebes, gave Helen.

The singer unmistakably evokes the image of Helen's silver talaros when she declares that the Alexandrian women grow Adonis" gardens in " $\tau \alpha \lambda \alpha \rho i ́ \sigma \kappa о 1 \varsigma$

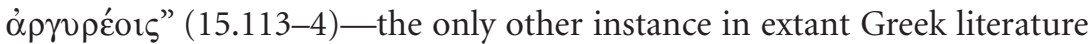
of a talaros, itself a rare object, ${ }^{29}$ being composed of silver.

By eliciting Homer's catalogue of Helen's domestic paraphernalia in Odyssey 4, Idyll 15 exhibits an allusive complex similar to Idyll 18. Like the "Epithalamium of Helen," Idyll 15 suggests that we imagine Arsinoe in terms of the post-Iliadic Helen Telemachus meets in Sparta. ${ }^{30}$ Comparison with the Helen of the Odyssey is flattering indeed. Helen, having returned to Sparta and spinning wool stored in her silver basket with a golden distaff, exemplifies a faithful wife impeccably entertaining the household's guests. Only a dim reflection of the notorious adulteress appears as she displays her semi-divine munificence throughout Telemachus's stay. ${ }^{31}$ She divines Telemachus's identity, comforts him with her story of Odysseus's daring, and pours out good drugs (also gotten from Egypt) to assuage Telemachus's and her husband's grief as they mourn Odysseus's absence. When Telemachus prepares to depart for Ithaca, Helen offers a final display of her feminine virtue and semi-divine power when she offers the budding hero a reassuring augury and a long, embroidered robe for his wedding day. From her grand entrance to final farewell in the Odyssey, Helen demonstrates a surfeit of the divine grace that comforts and counsels Telemachus and will one day divinize Menelaus. ${ }^{32}$

The poet's explicit comparison of Arsinoe to Helen, coupled with the allusions to Odyssey 4, caps the recurring pattern of representing Arsinoe in terms of the Odyssey's semi-divine epic queens. Like Helen, Arsinoe is a queen honored in Egypt whose divine and divinized ancestors along with her spectacular wealth, liberality, and piety all point to her own divinity

${ }^{29}$ Pantelia 78.

${ }^{30}$ Pantelia, esp. $79-80$.

${ }^{31}$ Encoded within Menelaus's story (Od.4.265-89) of Helen circling the Trojan Horse mimicking the wives of each hero in order to coax them from their lair is a very obvious reminder of her powers and inclination for duplicity. For a less sanguine view of Helen's benevolence in the Odyssey, see Austin 71-89.

${ }^{32}$ As Proteus prophesies at $O d .4 .561-69$. 
that will shortly be openly celebrated-if it is not already. ${ }^{33}$ Yet, Theocritus is not content to establish a mere equivalency between Arsinoe and her epic antecedents since the poet subtly but insistently affirms Arsinoe's superiority while stamping the wealth and power of the Ptolemaic household she oversees in an Egyptian mold.

Gorgo and Praxinoa may be traveling to the home of the Ptolemies but neither they nor the enormous crowd admitted within the palace precincts will catch a glimpse of their royal hosts. Gorgo, Praxinoa, and their fellow festival-goers-not to mention Aphrodite and Adonis-are not personally entertained by the hostess-queen but rather a cadre of professionals are assembled to produce and distribute her largess. ${ }^{34}$ Her freedom from the demands of domestic labor underscores Arsinoe's elevated, if not divine, status and her Egyptian environs where upper class women left spinning and weaving to servants or professionals. Homeric women as renowned as Penelope, Arete, and Helen and even immortals like Circe and Calypso may busy themselves with the shuttle, spindle, and loom, but certainly not Pharaoh's consort.

The adornment of her Adonia reminds the audience that her household is all of Egypt and the Eastern Mediterranean. ${ }^{35}$ Arsinoe's festival not only displays the specialized economy and centralized bureaucracy that oversee the kingdom, but also the staggering wealth at her disposal. Helen has one soft cover. Arsinoe has several-and Arsinoe's are purple. Helen's is soft. Arsinoe's are softer. Helen's wool is no doubt very fine. Arsinoe's the finest-gotten from Samian sheep herded at the edges of a realm all too ready to dedicate its resources and efforts to the aggrandizement of the house of Ptolemy. So too with Helen's precious silver talaros, now multiplied into the containers that hold Adonis' gardens. With the recurring emphasis upon her excess of wealth, her freedom from the demands of domestic autoarcheia, and her piously remote liberality, Theocritus repeatedly suggests that Arsinoe, so like her

${ }^{33}$ The cult of the Theoi Adelphoi was instituted circa 272/1 and Idyll 15 may well have been composed at that time as Gow (2.265) suggests, but it almost certainly was written after Philadelphus' incursions into Nubia in 275. For this terminus post quem, see infra, 16-7.

${ }^{34}$ Glotz 196-8 suggests that the foods prepared for Aphrodite and Adonis will subsequently be served to religious officials, generous donors, and honored guests (but certainly not company that either Gorgo or Praxinoa will keep) at an ensuing banquet, but there is absolutely no hint that the queen herself would preside over such a feast.

${ }^{35}$ Fraser 1.134 sees a direct analog between a Greek oikos and the Pharaoh's control of Egypt: "In the social and economic life inherited by the Ptolemies from the Pharaohs the countryside was the property of the king, and all the products of the land were at his disposal, just as the domestic products of a house were at the disposal of its master." 
epic analogs, nevertheless, ultimately proves her superiority just as the wealth, power, and prestige of Ptolemaic Egypt reaches beyond Homeric heights to the halls of Zeus himself. The poet does not fail to emphasize that point or Philadelphus' role in amassing the queen's wealth as the poet discernibly hints at the king's military conquests.

\section{PHILADELPHUS AS SESOSTRIS}

In the course of enumerating the materials comprising the queen's tableau, Arsinoe's hymnist exclaims (15.123-4; trans. Gow 1952):

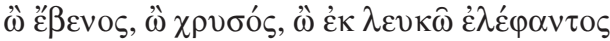

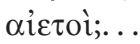

$$
\begin{aligned}
& \text { O ebony, } \mathrm{O} \text { gold, } \mathrm{O} \text { eagles of white ivory... }
\end{aligned}
$$

Like the immediately ensuing references to the soft covers and silver talaroi specifically located in Odyssey 4, the gold, the line closing "غ่ $\lambda \dot{\varepsilon} \varphi \alpha \nu \tau o \varsigma$ " and the triple homoioteleuta of 15.123 suggest an echo of Odyssey 4.73, where Telemachus shares his wonder at the glittering wealth filling Menelaus's halls with his companion, Peisistratus (Od. 4.71-5):

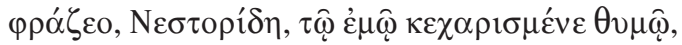

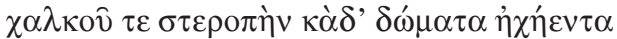

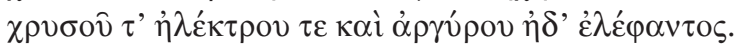

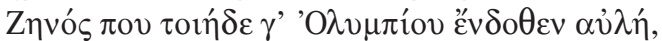

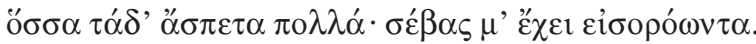

Son of Nestor, dear to my heart, consider the gleam of bronze, gold, electrum, silver and ivory in these echoing halls, perhaps such is in Zeus's courtyard inside Olympus - so marvelous these things before us are that wonder seizes me as I gaze upon them.

The recollection of Odyssey 4.73 reminds the audience that, like the Greek couple, Arsinoe and Philadelphus also have been laden with Egyptian gifts freely given. Telemachus's ensuing comparison of Menelaus's halls to Zeus's could not be more apropos of the Ptolemaic palace envisioned in Idyll 15 where goddesses, demigods, as well as mortal subjects are sumptuously entertained. Just as the evocations of the Helen of Odyssey 4 in Idyll 15 ring similar to the Helen depicted in Idyll 18, Idyll 15's allusion to Telemachus's comparison of Menelaus's halls with Zeus's establishes a strong intratextual resonance with the encomiastic themes Theocritus employs in Idyll 17. There those very halls of Zeus are populated by Ptolemaic ancestors enjoying an idealized version of a Greek symposium for which Ptolemy Philadelphus's own halls 
were so famous. ${ }^{36}$ Yet the singer's variations on Odyssey 4.73 are even more striking as they betray how the poet has overlaid the epic allusion with Greek historiographical traditions about Egypt to offer a vision of Philadelphus as a world conquering Pharaoh.

The singer's list of precious commodities and the locales that provide them not only heaps praise upon Arsinoe, but also broadcasts Philadelphus's role in the production. By emphasizing that the perfumes come from Syria and the wool from Samos, the singer's enumeration of the festal luxuriance becomes, as Whitehorne observes, "as much as a display of Philadelphus's power and prestige as it is of Arsinoe's skill and piety." ${ }^{37}$ Yet, like the continual revision upward of the poet's Homeric models to aggrandize Arsinoe, the singer alters the list of precious materials from her Homeric precursor at 15.123 to distinguish Ptolemy from Menelaus - a figure who must not be too closely associated with Philadelphus_-by impressing the image of the legendary Egyptian king Sesostris upon the poem's Homeric base.

Replacing Homer's electrum and silver with ebony and an adjective descriptive of ivory easily can be seen as more strongly localizing the Homeric wealth Arsinoe and Philadelphus enjoy in Egypt as the decidedly un-Homeric ebony (as well as the perfectly Homeric ivory) are affiliated with Egypt via Ethiopia (i.e. contemporary Nubia). Encoded within the singer's list of precious materials, like the mention of Samian wool and Syrian perfumes (15.114, 125-7), are subtle reminders of the extent of Ptolemaic power as part of Nubia like the Cyclades, Coele-Syria, and portions of Asia Minor had (at least temporarily) come under Ptolemaic influence in the $270 \mathrm{~s} .{ }^{38}$ Beyond a vague recollection of contemporary conquests, the poet slyly conjures the image of Sesostris and with it intimations of Ptolemy as Pharaoh and world conqueror.

According to Hecataeus, in a fragment preserved in Diodorus Siculus, one of Sesoösis's (i.e. Sesostris) first campaigns was directed against his southern neighbors, the Ethiopians (i.e. Nubians) (FGrH 264 F 25.55.1=D.S. 1.55.1):

${ }^{36}$ See especially Idyll 17.16-33; Hunter 2003: 110-24. If one recollects Telemachus's comparison, the allusion only underscores the religious/political propaganda encoded in Theocritus choosing to compose the eagles that will translate Ganymede to heaven with materials drawn from Odyssey 4.73. Evoking the halls of Zeus coupled with the representation of a figure that will be translated to them sharpens a proleptic vision of the pharaonic destiny that awaits Arsinoe and Philadelphus expressed in terms of Greek mythology. Cf. Idyll 17.45-50 (Berenice's translation to heaven); Callimachus, "Ektheosis Arsinoes" (fr. 228 Pfeiffer). For a summary of the poetic strategies employed in the latter, see Hunter 2003: 50-3.

${ }^{37}$ Whitehorne 73.

${ }^{38}$ Discussed most recently by Hölbl 37-58, esp. 55-8. 


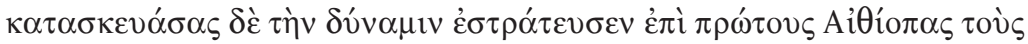

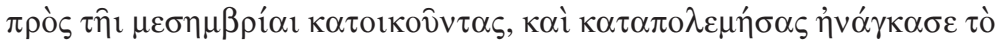

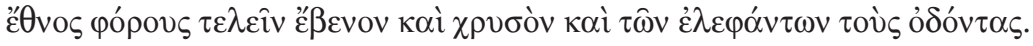

After making preparations, he first waged war against the Ethiopians who live to the south. Having defeated them, he compelled the nation to pay tribute, ebony, gold, and tusks of ivory.

The tribute he extracts from the conquered Ethiopians precisely parallels the materials decorating Arsinoe's festal scene. Certainly a desire to replicate the exact sequence of precious goods given by Hecataeus would explain the

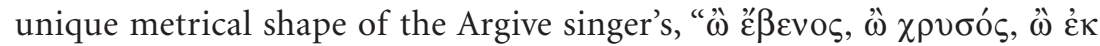
$\lambda \varepsilon v \kappa \hat{\omega} \varepsilon \dot{\varepsilon} \lambda \dot{\varepsilon} \varphi \alpha \nu \tau o \varsigma^{\prime \prime 39}$ Theocritus exhibits familiarity with Hecataeus's account

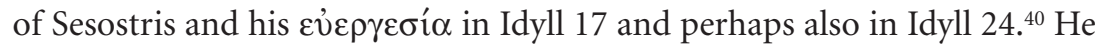
explicitly celebrates Ptolemy's successful incursions into Nubia at 17.86-7:

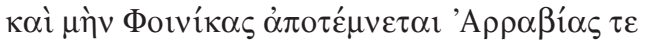

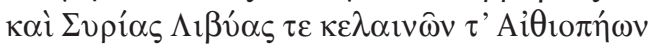

And he cuts off for himself part of Phoenicia, Arabia, Syria, Libya and of the dark Ethiopians.

There can be little doubt that Theocritus has embellished the Idyll's echo of Od. 4.73 with historical references he employs elsewhere in his poetry. The Greek hero receiving gifts from Egyptians is amalgamated with the Egyptian king extracting tribute from Ethiopians. Theocritus thus creates a unique alloy of images that reflects the Ptolemies' unique condition of Greek conquerors assuming a pharaonic identity.

Likening Philadelphus to Sesostris underscores Arsinoe's difference from her epic counterparts. Arsinoe's home does not simply resemble the Sparta of Helen adorned with Egptian luxuries. Arsinoe's home is Egypt; her husband is the divine Pharoah. Theocritus reminds his audience that for all of her resonace with Greek epic heroines Arsinoe is also an Egyptian queen overseeing an extraordinary Egyptian home adorned with unimaginable wealth that has been freely given by admiring subjects or rightly taken by her consort's martial prowess.

\section{CONCLUSION}

Theocritus was a court poet and wrote encomia as we would expect. Idyll 17 openly revels in Ptolemy Philadelphus's proclaimed divinity. Idylls 7 and 14

${ }^{39}$ The combination of first and fifth foot hiatus and irrational lengthening in the second foot is unique to Theocritus' corpus.

${ }^{40}$ Stephens 144-6, 159-61. 
sing his praises. Idylls such as 18, 22, 24, and 26 all appropriate Greek literary and mythological traditions to forge within hymns, wedding songs, and "epyllia” suggestive links_ — often tempered with an Egyptian alloy-between Greek gods and heroes and Theocritus's new found patrons. Idyll 15 exemplifies the poet's often peculiar encomiastic practices. A low mimetic genre amalgamated with a lyric hymn recast into hexameters becomes the framework by which Theocritus not only presents a slice from the upper crust of Alexandrian Greek domestic life, ${ }^{41}$ but also adorns his representation of Arsinoe's Adonia with an encomiastic façade created from allusions to high epic hospitality scenes. Throughout Idyll 15 Gorgo, Praxinoa, and especially the Argive singer tincture the wonderous sights, melodious sounds, and savory odors of the Adonia with Homeric tones highlighting Arsinoe's role as "mistress of the house" entertaining her train of admiring guests.

The poet's focus upon Greek epic heroines with Egyptian connections amalgamated with a vision of Egypt mediated through Herodotus and Hecataeus brilliantly recasts his allusions to Arete, Circe, and Helen not only to emphasize Arsinoe's impeccable hospitality, but also her unique status as both Greek and Egyptian, mortal and immortal. With this clever hybrid of epic and history, Theocritus subtly but emphatically broadcasts Arsinoe's resonance with and dissonance from the epic queens she resembles, emulates, and ultimately surpasses.

\section{WORKS CITED}

Arend, W. 1933. Die typischen Scenen bei Homer. Berlin.

Austin, N. 1994. Helen of Troy and Her Shameless Phantom. Ithaca.

Bevan, E. 1927. The House of Ptolemy: A History of Egypt Under the Ptolemaic Dynasty. London.

Bowie, E. L. 1985. “Theocritus' 7th Idyll, Philetas and Longus.” CQ 35: 67-91.

Brown, E. L. 1981. “The Lycidas of Theocritus' Idyll 7.” HSCP 85: 59-100.

Burstein, S. 1982. “Arsinoe II Philadelphus: A Revisionist View.” In W. L. Adams and E. N.

Borza, eds., Philip II, Alexander the Great and the Macedonian Heritage. Washington DC. 197-212.

Burton, J. B. 1995. Theocritus's Urban Mimes: Mobility, Gender, and Patronage. Berkeley. Donzelli, G. B. 1984. “Arsinoe simile ad Elena.” Hermes 112: 306-16.

Dover, K. J. 1987. Theocritus: Select Poems. Oak Park, IL.

Fantuzzi, M., and R. L. Hunter. 2002. Muse e Modelli: la poesia ellenistica da Alessandro Magno ad Augusto. Rome.

Foster, J. A. 2002. Structured Polyphony: Narrative Framing and Reception in Theocritus, Idylls 6, 15, and 24. Ph.D. diss., University of Chicago.

Fraser, P. M. 1972. Ptolemaic Alexandria. Oxford.

${ }^{41}$ As Whitehorne 66-70 persuasively argues, Gorgo and Praxinoa are rather wealthy. 
Glotz, G. 1920. “Les fêtes d'Adonis sous Ptolémée II.” REG 33: 169-222.

Gow, A. S. F. 1938. “The Adoniazusae of Theocritus." JHS 58: 180-204.

—, ed. 1952. Theocritus. 2 vols. Cambridge. , and D. L. Page, eds. 1965. Hellenistic Epigrams. Cambridge.

Green, P. 1990. Alexander to Actium: The Historical Evolution of the Hellenistic Age. Berkeley.

Griffiths, F. T. 1979. Theocritus at Court. Mnemosyne, Bibliotheca Classica Batava: Supplementum 55. Leiden.

_. 1981. "Home Before Lunch: The Emancipated Woman in Theocritus." In Helene P. Foley, ed., Reflections of Women in Antiquity. New York. 247-73.

Hazzard, R. A. 2000. Imagination of a Monarchy: Studies in Ptolemaic Propaganda. Toronto.

Heubeck, A., S. West, and J. B. Hainsworth. 1988. A Commentary on Homer's Odyssey. Oxford.

Hölbl, G. 2001. A History of the Ptolemaic Empire. Translated by T. Saavedra. New York. Hunter, R. L. 1996. Theocritus and the Archaeology of Greek Poetry. Cambridge.

-1999. Theocritus: A Selection. Cambridge. 2003. Theocritus: Encomium of Ptolemy Philadelphus. Berkeley.

Koenen, L. 1977. Eine agonistische Inschrift aus Ägypten und frühptolemäische Königsfeste. Edited by R. Merkelbach and C. Zintzen. Beiträge zur klassischen Philologie. Meisenheim am Glan.

Legrand, P. E., ed. 1927. Bucoliques grecs. 2 vols. Paris.

- 1898. Étude sur Théocrite. Bibliothèque des Écoles francaises d'Athènes et de Rome; fasc.79. Paris.

Macurdy, G. H. 1932. Hellenistic Queens; A Study of Woman-Power in Macedonia, Seleucid Syria, and Ptolemaic Egypt. Baltimore.

Mori, A. 2001. "Personal Favor and Public Influence: Arete, Arsinoë II, and the Argonautica." Oral Tradition 16, no. 1: 85-106.

Page, D. L. 1962. Poetae Melici Graeci. Oxford.

Pantelia, M. 1995. “Theocritus at Sparta: Homeric Allusions in Idyll 18.” Hermes 123: 76-81.

Pedrick, V. 1988. “The Hospitality of Noble Women in the Odyssey." Helios 15, no. 2: 85-101.

Pfeiffer, R., ed. 1953. Callimachus. Oxford.

Pomeroy, S. 1984. Women in Hellenistic Egypt From Alexander to Cleopatra. Detroit.

Reece, S. 1993. The Stranger's Welcome: Oral Theory and the Aesthetics of the Homeric Hospitality Scene. Ann Arbor.

Reed, J. D. 2000. “Arsinoe's Adonis and the Poetics of Ptolemaic Imperialism." TAPA 130: 319-51.

Stephens, S. A. 2003. Seeing Double: Intercultural Poetics in Ptolemaic Alexandria. Berkeley.

Wendel, C., ed. 1967. Scholia in Theocritem Vetera. Stuttgart.

Whitehorne, J. 1995. "Women's Work in Theocritus, Idyll 15." Hermes 123: 63-75. 